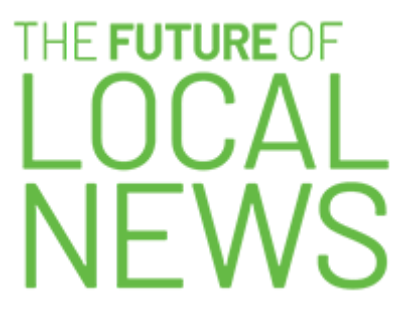

\title{
The Local News Map
}

\section{Transparency, credibility, and critical cartography}

April Lindgren, Ryerson University

Jon Corbett, University of British Columbia

\section{Keywords}

local news

mapping

local journalism

participatory mapping

crowdsourcing

critical cartography

\section{Abstract}

Widespread disruption has made tracking what is happening to local journalism in Canada a challenge. The Local News Map is a crowdsourced web-based mapping tool that invites the public to contribute information about local newsroom startups, closings, and service reductions/increases. As concerns mount about the future of local journalism, the map's data are cited with increasing frequency and it has the potential to influence debate, policy, and other research. Taken at face value, the map is a straightforward tracking device. [read more="Read 
More" less="Read Less"|A critical assessment of the assumptions, decision-making, and biases underpinning the map, however, illustrates that nothing is ever quite that simple. Researchers have called for a more critical and reflective approach to the application of geographic information technologies to mapping. This article draws on theories of critical cartography to evaluate the Local News Map's biases, limitations, and strengths with a view to enhancing its credibility as a research tool. [/read]

\section{Introduction}

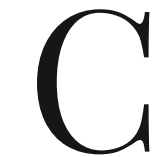

ity councillor James Gordon's indignation was palpable as he talked about what has happened in Guelph, Ontario, following the demise of the 148-year-old Guelph Mercury newspaper in early 2016. In the absence of a daily paper to provide citizens with verified news and information, he told delegates attending a conference on the future of local journalism, extreme views fueled by online comments and blogs are becoming more influential in Guelph, a city of 132,ooo located about an hour's drive west of Toronto (Bala, 2017). Gordon's concerns were echoed in a subsequent Globe and Mail story about Guelph's “post-Mercury blues” (Houpt, 2017). An online news site, a rebranded community newspaper, and a local political blogger still provide basic coverage of news and events, the story says. But they are not meeting the needs of a citizenry in "despair over a growing sense that city politics are becoming nastier and more polarized without the moderating influence of a daily" to provide the more in-depth, nuanced stories that inform debate and foster compromise.

Disquiet about the Guelph situation following the loss of the Mercury was soon overshadowed by widespread shock in the fall of 2017 when Postmedia Network Canada Corp. and Torstar Corp. announced a newspaper swap involving 41 papers and the subsequent closing of three dozen of the publications (Evans, 2017). The manoeuvre fuelled speculation about Postmedia's viability: Ongoing financial losses at the country's largest newspaper chain (Canadian Press, 2017) have led to round after round of layoffs and cost cutting at its publications which, even after the latest closings, still include more than 40 daily newspapers and upwards of 100 non-daily community papers (Postmedia, 2016).

The fragility of local news ecosystems is not only confined to the newspaper sector. While the major television networks announced new local evening newscasts in a number of markets in 2017 (Bell Media, 2017; Rogers Media, 2017; Watson, 2017), a study commissioned by the lobby group Friends of Canadian Broadcasting has warned that, in the absence of intervention by Canada's broadcast regulator, more than half of the country's independent stations (stations not owned by vertically integrated media conglomerates like Rogers and Bell) in small and medium-sized markets will be off the air by 2020 (Friends of Canadian Broadcasting, 2016).

Concerns during the winter of 2016 about the availability of local news in communities across the country prompted the House of Commons Standing Committee on Canadian Heritage to launch hearings on "how Canadians, and especially local communities, are informed about local and regional experiences, through news, broadcasting, digital and print media” (Ditchburn, 2016). During the course of its 18-month Media and Local Communities study, the committee heard repeatedly about the lack of solid information on whether the essential information needs of Canadians are being met. On the second day of hearings in February, 2016, the University of Laval's Francois Demers testified that it is not clear who the main producers are in terms of local/regional information (Canada, House of Commons, Standing Committee on Canadian Heritage, 2016). Monica Auer, the executive director of the Forum for Research and Policy in Communications, noted that the country's broadcast regulator, the Canadian Radio-Television and Telecommunications Commission, does not have key data related to 
local broadcast news. The number of journalists employed by stations and their newsgathering capacity is unknown, she said. No data are available on the amount of local news produced by Canadian radio stations and information on how much original local news television stations produce is unreliable: "There are very few facts about Canadians' overall access to original local broadcast news concerning their communities or about stations' capacity to actually gather this news," Auer concluded (Canada, House of Commons, Standing Committee on Canadian Heritage, 2016, p. 3). Carleton University professor Dwayne Winseck, meanwhile, warned of "severe" shortages of data about changes to the media landscape and observed that there are "a lot of opinions and little data to act upon" (Canada, House of Commons, Standing Committee on Canadian Heritage, 2016, p. 5). In addition to the paucity of local news data for the broadcast sector, there is no comprehensive listing of local online digital news sites, and reliable data on the newspaper sector is increasingly unreliable and unavailable. Since 2011, News Media Canada, which represents daily and community papers (published fewer than four times per week), has tracked developments at its approximately 800 member publications and combined the data on closings, launches, and mergers with details of what is happening at the more than 300 non-member publications identified by its researchers (Kelly Levson, personal communication, August 1, 2017). Many small publications, however, are not included in the list. Moreover, many financially strapped newspapers have discontinued official circulation audits to cut expenses and this has led News Media Canada to stop publishing daily newspaper circulation numbers for individual titles in 2016 (Canadian Media Concentration Research Project, 2017; News Media Canada, n.d.).

The Local News Map, a joint project of researchers at Ryerson University and the University of British Columbia, was created in response to the dearth of reliable information about rapidly evolving local news media ecosystems in Canada. In the same way that the scientific community has appealed to the public for information on everything from bird counts to local environmental assets and hazards (Williamson \& Connolly, 2009), the crowdsourced map launched in June, 2016 invites the public to contribute information about changes to local print, digital, and broadcast media news outlets (Ghosh, 2016). Over the first 16 months of its existence, the web-based mapping tool and the data it generates have been cited in numerous stories about the upheaval in Canada's news industry (Kerr, 2016; Wallace, 2017), referenced in think tank studies (Public Policy Forum, 2017), and highlighted by members of parliament in the Heritage committee's final report, which urged Canadians to consult the participatory tool to "see the changes affecting the supply of local news in their region" (Canada, House of Commons, Standing Committee on Canadian Heritage, 2017, p. 15). 


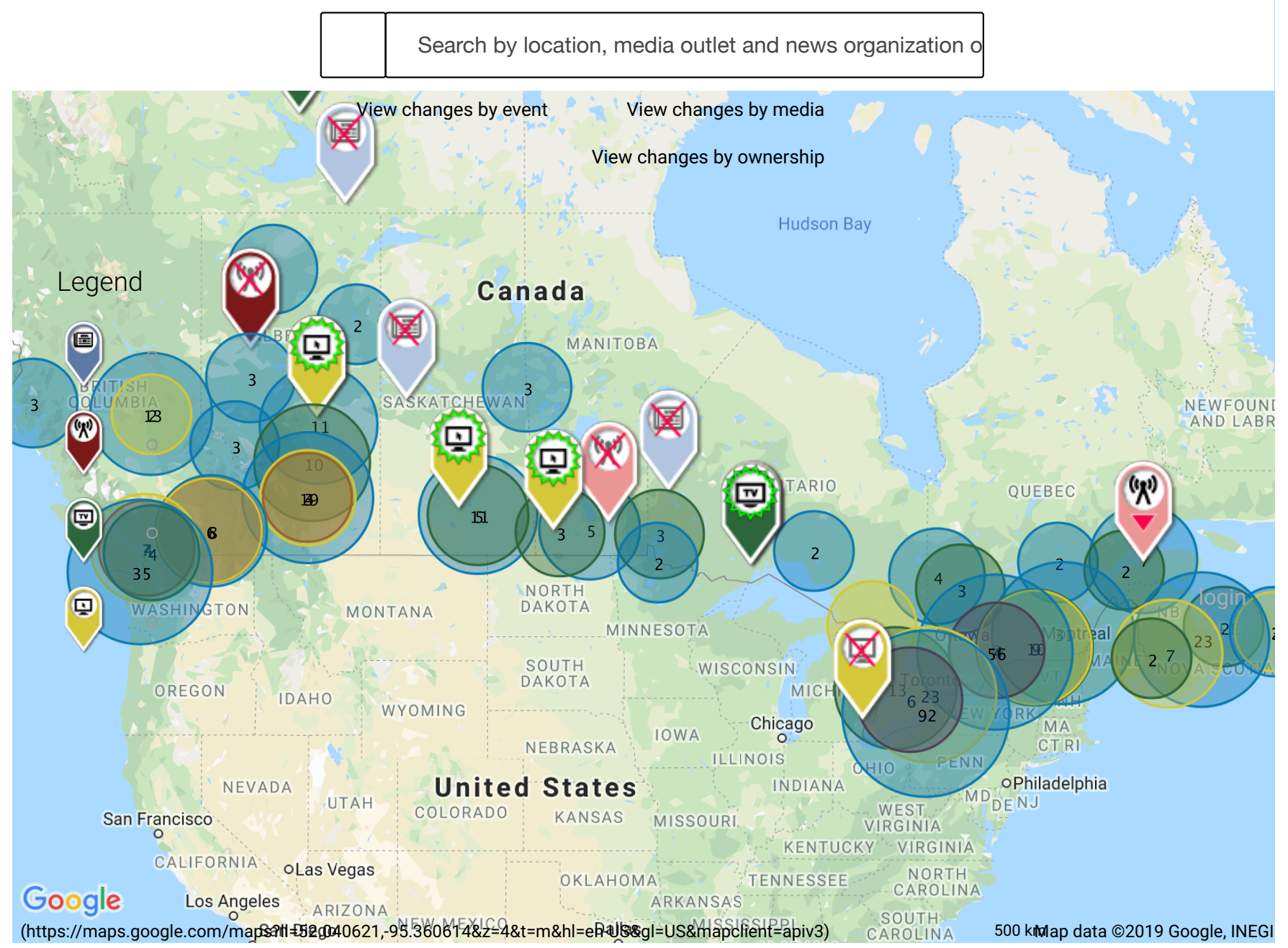

Given the map's potential to influence debate and policy making at a time of growing angst about the future of local journalism, important questions about the accuracy of its data and the biases and assumptions embedded in the map-making process merit consideration. In the same way that transparency of journalistic method-making it clear to the audience where and how information was obtained-is considered essential to the credibility of reporters' work (Kovach \& Rosenstiel, 2014), transparency in the map-making process is essential to the Local News Map's credibility as a tool for research about the state of journalism in Canada. Critical cartographers in the 1980 s began challenging the notion of maps as purveyors of objective, neutral truth (Harley, 1989; Kitchin, Perkins, \& Dodge, 2009) and more recently scholars have been calling for a similarly critical and reflective approach to cartography that employs geographic information technologies (Allen \& Queen, 2015). Mapmakers' decisions and conscious and unconscious assumptions influence the stories maps tell and therefore need to be critically examined in a way that reveals the iterative, exploratory, and comparative characteristics of maps as well as their less-than-obvious subtexts. This paper deconstructs the Local News Map using this approach. Potential biases and key design decisions that contribute to its strengths and weakness are identified in what is essentially an exercise in transparency, one designed to bolster confidence in the map as a tool for identifying trends, generating research questions, and producing reliable data on changes to local news ecosystems in Canada. 


\section{0}

Ryerson University
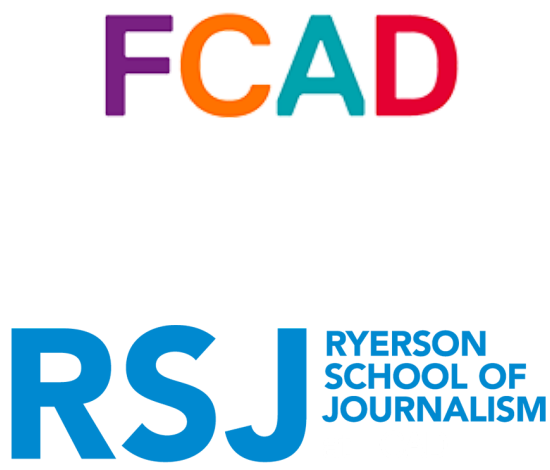

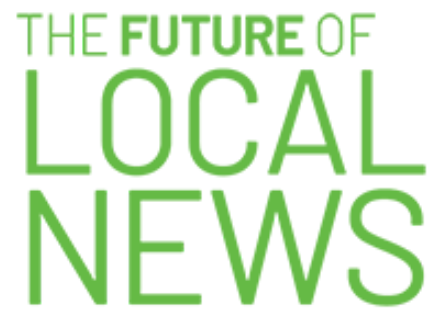

Research and Reflections

\section{ABOUT OUR \\ PUBLICATION}

This multimedia

publication, The Future of

Local News: Research and

Reflections, is the

culmination of several

years of academic research,

complemented by a year of

student journalism, an

international conference,

and a cross-Atlantic

editorial collaboration

focused specifically on the

current and future state of

local news around the

world.
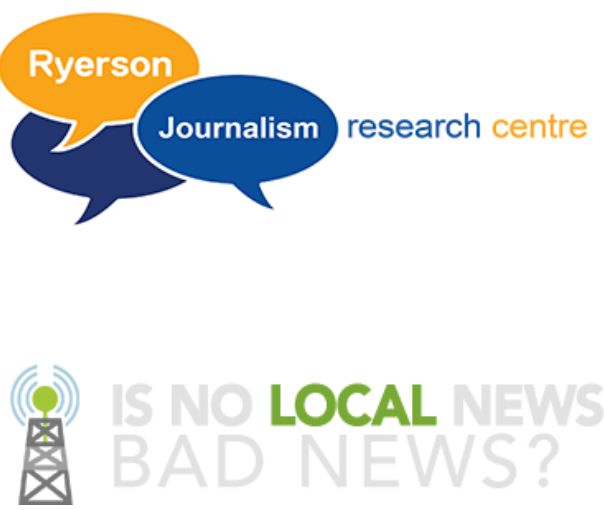

(C) 2019 The Future of Local News | Ryerson Journalism Research Centre

If you have questions or concerns, please contact the Ryerson Journalism Research Centre here.

\section{(c) $\underset{\mathrm{EY}}{(\mathrm{N} \mathrm{N}}$}

This work is licensed under a Creative Commons Attribution-NoDerivs 2.5 Canada License. 